\title{
Hay harvesting services respond to market trends
}

by Steven Blank, Karen Klonsky, Kate Fuller, Steve Orloff and Daniel H. Putnam

\section{In recent years, there has been a} trend in California from harvesting hay in small hay bales of about 125 pounds to very large bales of 1,300 pounds or more. This shift is driven by both production considerations and the preferences of some consumers, but has significant implications for the hay market and its many consumer segments. We conducted a survey of rates and the rate-setting methods among custom alfalfa hay harvesters in the northern intermountain region and the San Joaquin Valley. The results show that large bales are cheaper to produce than small bales.

$\mathrm{T}$ he alfalfa hay industry is undergoing a transition in its harvesting technologies that has significant implications for hay growers and consumers. Hay is one of the few agricultural commodities that are "packaged" for the retail market during the initial harvest. Hay buyers prefer some physical attributes over others (Ward 1987) and hay pricing is affected by quality attributes (Hopper et al. 2004), but little attention has been paid to how the alfalfa harvesting process affects hay prices and market structure. We examine how harvesting service costs charged to growers have been influenced by the shift from small to large bales.

Hay harvesting services and costs are important concerns for alfalfa growers. The functions involved in harvesting hay must be performed on a fairly rigid schedule to maximize profits (Blank et al. 2001). However, many growers cannot afford to own the complete set of machines needed to harvest hay in a timely manner, or they may be averse to the risk of harvest delays due to mechanical breakdowns of the equipment (Blank et al. 1992). As a result, those

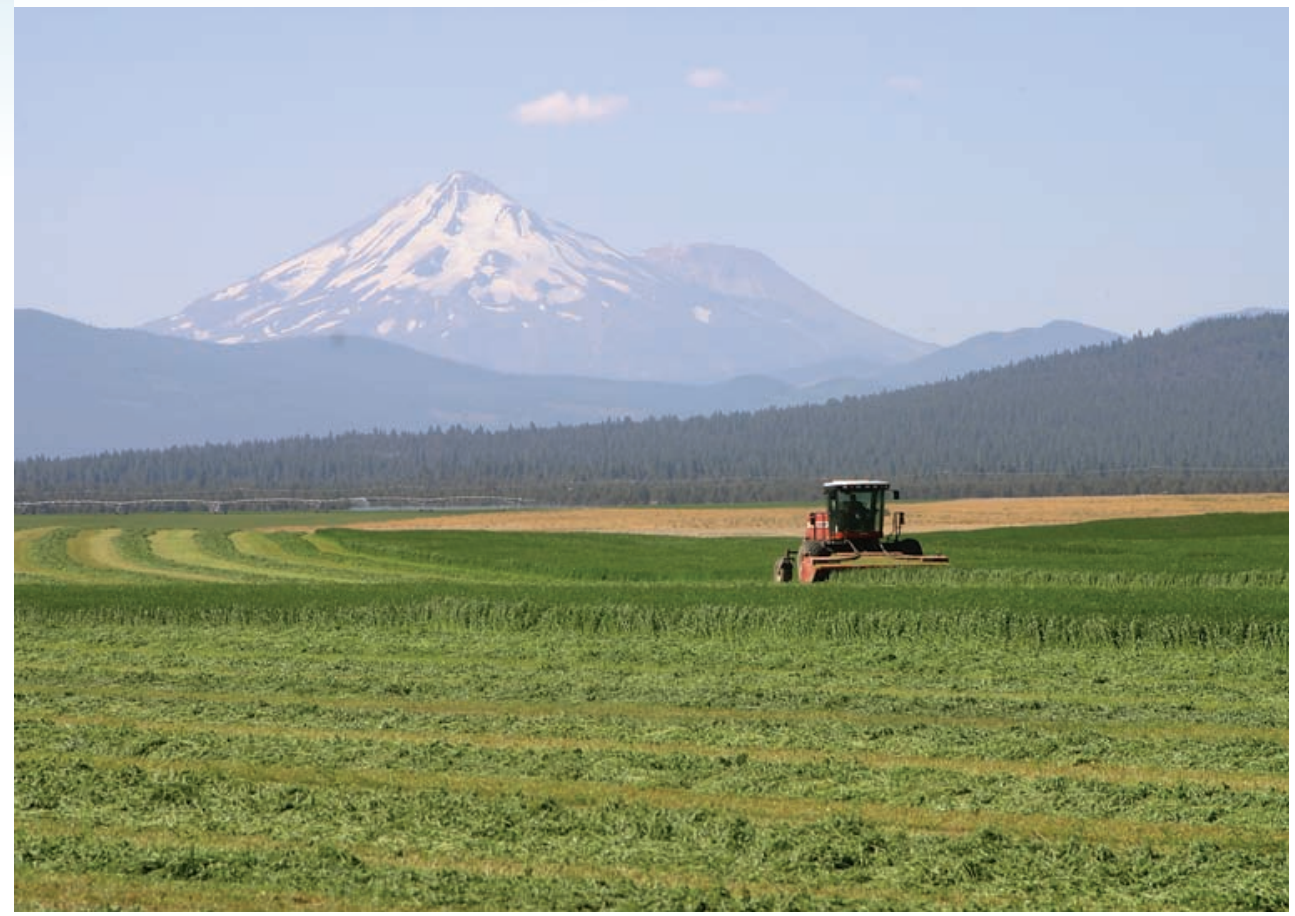

Hay is one of the few crops that is harvested and "packaged" in the field. New harvesting technologies are having important impacts on growers and consumers. Above, a rotary-type swather cuts alfalfa in Butte Valley (Siskiyou County), beneath Mt. Shasta.

alfalfa growers hire "custom harvesters" to perform some or all of the harvest functions for them. Those functions include swathing (cutting the alfalfa), raking the cut alfalfa into rows (to facilitate the drying process), baling the dry alfalfa and roadsiding (using a mechanical bale stacker to move the harvest to the side of the field or to a barn).

Custom harvesting firms must be efficient in minimizing their costs to maintain a profit margin adequate for survival, so they are quick to adopt new technology. In California, more than $70 \%$ of custom hay harvesters have purchased new-generation balers that create large, rectangular bales. The ongoing transition from traditional bales of 125 pounds or less to large bales of 1,300 pounds or more is changing both the equipment needed to harvest the hay, and the hay market itself. This has wide-ranging implications for both hay growers and hay consumers. Many livestock producers do not own the equipment necessary to handle large bales. Only hay consumers with a hay "squeeze" (a special type of forklift used to pick up large hay bales) want large bales, so small-scale hay consumers - such as horse owners - are seeing their sources decrease in number as more growers produce only large bales.

\section{Hay market survey}

Alfalfa is important in California. It is the state's highest acreage crop, typically with close to a million acres. California produces about 7 million tons annually, more than any other state. California's more than $\$ 1$ billion hay market is driven by the dairy industry and its demand for hay.

Rather than a single market, California has regional hay markets with different production practices that result in different harvest pricing practices and levels for alfalfa hay harvesting services (Konyar and Knapp 1990). Therefore, we collected data from two different regions of California: the intermountain region in the far north, and the San Joaquin Valley in Central California. About $61 \%$ of the state's total alfalfa production is in the San Joaquin Valley and $10 \%$ is in the intermountain region.

A telephone interview was conducted during autumn 2007 with some 
follow-up interviews in 2008. A representative sample of custom harvesters from each region was contacted and asked a series of questions about their operations. The sample included approximately one-third of the custom operators in each region, totaling 15: five harvesters from the intermountain region and 10 from the San Joaquin Valley. The respondents were selected from a list of custom operators compiled from hay industry sources and UC Cooperative Extension personnel. Respondents each served multiple alfalfa growers across the geographic regions, representing entire market areas. Our confidence in the representativeness of our results is high because we spoke to approximately one-third of the firms in the regional industries, and because the competitive nature of the industry causes harvesting firms to operate in similar ways to one another.

The results address hypotheses involving financial and performance issues arising from the shift from small to large bales. Financial issues include the hypothesis that purchasing new equipment to produce large bales increases the harvester's average fixed cost per ton. Performance issues include two related hypotheses. First, less time is needed to perform baling, and hauling and roadsiding, for large bales compared to small bales, and second, custom harvesters will charge less for harvesting large bales.

\section{Respondents and their balers}

Responses to descriptive questions provided a snapshot of the alfalfa hay harvesting industry across California. Of respondents, $60 \%$ harvested their own hay and did custom harvesting, $13 \%$ harvested their own hay only and $27 \%$ did only custom work. In total, 93\% did small and about 73\% did large baling, with large bales averaging 1,315 pounds. All respondents who did large baling also did small baling. Finally, 13\% did silage/chop harvesting, which involves chopping wilted forage into smaller segments so the forage can be preserved as silage rather than hay. The total number of acres serviced by all the harvesters that we surveyed in 2007 was 27,290, with a range of 190 to 5,000 acres for individual harvesters. Those harvest- ers doing custom work had between 1 and 17 customers annually, with an average of about 7 .

Respondents possessed a total of 74 balers. Fifty $(68 \%)$ were small balers, while $24(32 \%)$ were large. Forty-two (57\%) were bought new, and $32(43 \%)$, used. The years of purchase ranged from 1977 to 2007, with the oldest balers being unusual cases. The majority of purchases were made in 2004 or later. Of the used balers, the age at purchase was between 1 and 19 years, 7.2 years on average. Respondents estimated that their balers would last another 0 to 20 years, with an average of 6.2 years of lifetime from the present. The balers were purchased for between $\$ 7,000$ and $\$ 95,000$, at an average price of $\$ 42,081$. Over the entire sample of new and used equipment, estimated annual repair costs were between $\$ 850$ and $\$ 10,000$ per baler, with an average of $\$ 4,165$.

As hypothesized, the data indicated that purchasing new equipment to produce large bales increased a harvester's average fixed cost per ton. However, average annual operating costs appeared to decrease slightly with large balers. Harvesters that purchased new balers during 2007 paid an average price of $\$ 88,000$ for large balers and $\$ 49,500$ for small, with average estimated annual repair costs of $\$ 850$ for large and $\$ 3,050$ for small balers. Other operating costs such as labor were generally lower for large balers, so the choice between large and small balers is not obvious.

\section{Regional production differences}

Due to geographic and microclimate differences between the regions that we studied, cultural practices in each resulted in significant output differences. The intermountain region has more difficult terrain and a shorter growing season than the San Joaquin Valley. Climate differences are significant, resulting in far fewer cuttings per year and higher average yields per cutting in the wetter intermountain region (table 1). This is significant because yield is an important factor in determining custom harvesting costs. Also, harvesters gave a broad range of responses in each region to questions about their average, smallest and largest jobs in 2007, and jobs in the San Joaquin Valley tended to be bigger, on average (table 2).

\begin{tabular}{|c|c|c|}
\hline \multicolumn{3}{|c|}{$\begin{array}{l}\text { TABLE 1. Differences in cuttings and } \\
\text { yield between regions }(n=15)\end{array}$} \\
\hline Cuttings & Intermountain & $\begin{array}{c}\text { San Joaquin } \\
\text { Valley }\end{array}$ \\
\hline & \multicolumn{2}{|c|}{ no. per field per year } \\
\hline Average & 2.8 & 7.1 \\
\hline Range & $2-4$ & $6-10$ \\
\hline First cutting & \multicolumn{2}{|c|}{ tons/acre } \\
\hline Average yield & 2.3 & 1.25 \\
\hline Low end* & 1.5 & 0.8 \\
\hline High end & 2.8 & 1.7 \\
\hline \multicolumn{3}{|l|}{ Last cutting } \\
\hline Average yield & 1.3 & 0.9 \\
\hline Low end & 0.9 & 0.6 \\
\hline High end & 1.7 & 1.3 \\
\hline $\begin{array}{l}\text { Average total } \\
\text { annual yield }\end{array}$ & 5.6 & 8.4 \\
\hline
\end{tabular}

\begin{tabular}{lcc}
\multicolumn{2}{c}{ TABLE 2. Differences in job size between regions } \\
\hline \hline Job size & Intermountain & $\begin{array}{c}\text { San Joaquin } \\
\text { Valley }\end{array}$ \\
\hline & $\ldots \ldots \ldots \ldots$ & acres $\ldots \ldots \ldots$ \\
Average & $30-300$ & $50-1,500$ \\
Smallest & $10-40$ & $7.5-1,500$ \\
Largest & $80-1,000$ & $180-2,000$ \\
\hline
\end{tabular}

\section{Custom harvesting parameters}

Custom harvesters' costs are affected by many variables. The two most important factors that create differences in a harvester's costs between one job and another are yield levels and the size of the job (expressed in total acres).

Fixed and variable costs. Hay harvesting has both fixed and variable costs. Fixed costs - annual costs that are generally fixed no matter how much the equipment is used - include payments on loans taken out to purchase the equipment, insurance and depreciation. Variable costs are directly related to equipment operation and vary by how much the equipment is used; these costs include fuel, labor and repairs.

Fixed costs expressed on a per-acre basis are most useful in explaining cost differences between one harvester and another, but do not normally influence costs specific to one job versus another. Two custom harvest firms will most often have different fixed cost totals, and in turn, different average fixed costs per acre harvested, even if they harvest the same number of acres per year. In addition, because different numbers of acres 


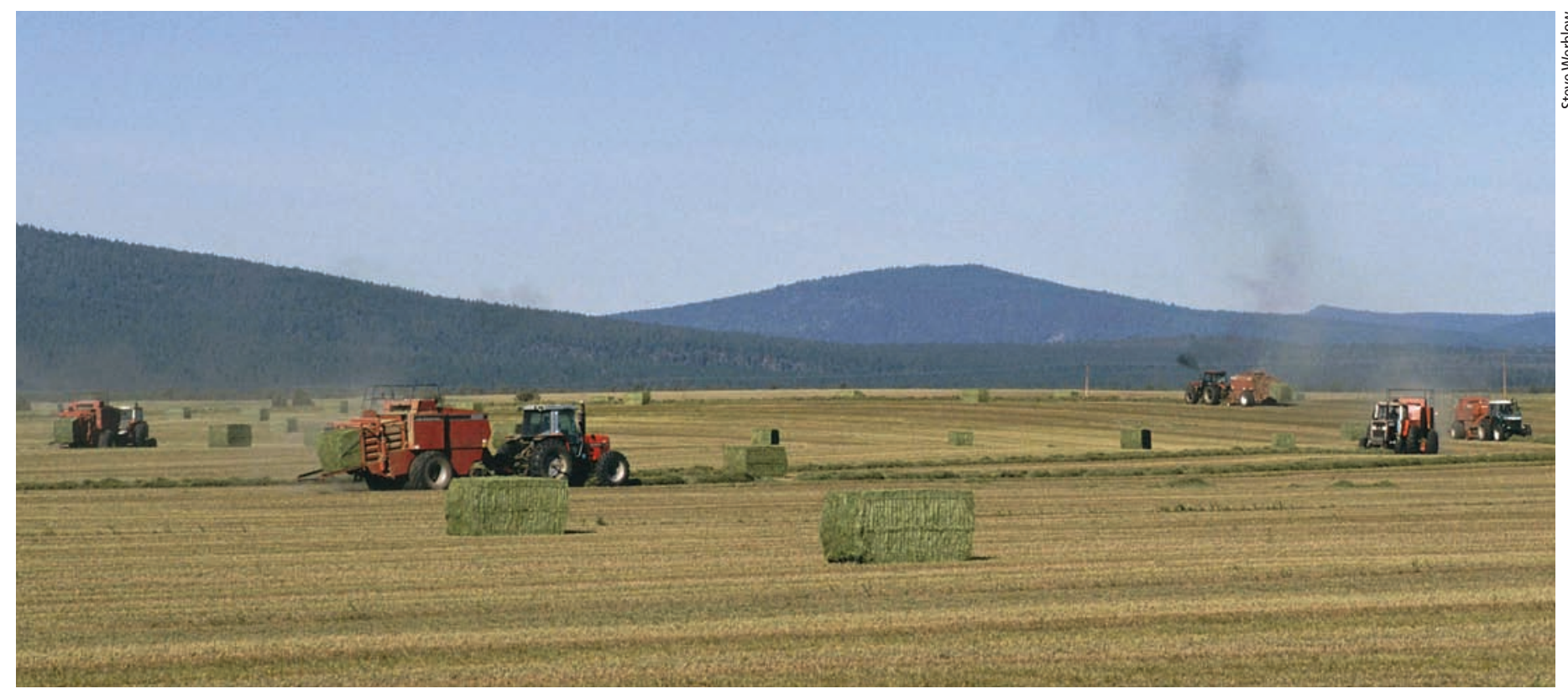

There has been an ongoing transition from small bales averaging 125 pounds to very large bales of about 1,300 pounds or more. This trend is influencing how hay-harvesting services are priced in California's intermountain region (shown, Butte Valley) and the San Joaquin Valley.

are served each year, average fixed costs per acre differ between firms. As a result, two or more harvesters can be expected to have different rate structures for a similar harvest job due to their differences in fixed costs.

Variable costs per acre are often similar between two or more harvest firms in a region, because fuel, labor rates and other costs tend to be similar. As a result, two or more firms bidding on the same job will have similar variable costs on a per-acre basis, assuming that they use similar equipment. If less time is needed to perform baling, and hauling and roadsiding, for large bales compared to small bales, as hypothesized, then custom harvesters may charge less for harvesting large bales because those bales are less costly to make.

Yield. Yield was the single most important job-specific influence on alfalfa hay harvester costs on a per-acre basis; survey respondents indicated that more time was needed per acre as yield increased. In both the intermoun- tain region (table $3 \mathrm{~A}$ ) and San Joaquin Valley (table 3B), more time was needed to perform harvest operations as average yields increased for both small and large bales. Basically, higher yields take more time per acre to harvest because the equipment has to slow down to process the more-dense alfalfa fields. More time means more variable costs, justifying a higher price.

In addition, baling, and hauling and roadsiding, were both faster for large bales compared to small bales in
TABLE 3A. Acres per hour by operation at varying yields, intermountain region

\begin{tabular}{|c|c|c|c|c|}
\hline \multirow[t]{2}{*}{ Operation } & & 1 ton/acre & 2 tons/acre & 3 tons/acre \\
\hline & & $\ldots \ldots \ldots$ & es per hour. & $\ldots \ldots \ldots$ \\
\hline \multirow[t]{3}{*}{ Swath $(n=5)$} & Low & 7.0 & 6.0 & 4.0 \\
\hline & High & 18.0 & 16.0 & 14.0 \\
\hline & Average & 12.2 & 10.0 & 8.3 \\
\hline \multirow[t]{3}{*}{ Rake $(n=5)$} & Low & 6.0 & 7.0 & * \\
\hline & High & * & 15.0 & * \\
\hline & Average & 10.6 & 10.4 & 9.9 \\
\hline \multirow[t]{3}{*}{ Bale/small $(n=5)$} & Low & * & 4.0 & 2.0 \\
\hline & High & 10.0 & 8.0 & 5.0 \\
\hline & Average & 7.4 & 5.6 & 3.6 \\
\hline \multirow{3}{*}{$\begin{array}{l}\text { Haul small bales off } \\
\text { field }(n=5)\end{array}$} & Low & 3.5 & 1.7 & 1.5 \\
\hline & High & 17.5 & 10.5 & 7.0 \\
\hline & Average & 11.2 & 7.0 & 4.8 \\
\hline \multirow[t]{3}{*}{ Bale/large $(n=3)$} & Low & 10.0 & 9.5 & 7.0 \\
\hline & High & 17.0 & 15.0 & 10.0 \\
\hline & Average & 13.0 & 12.2 & 8.7 \\
\hline \multirow{3}{*}{$\begin{array}{l}\text { Haul large bales off } \\
\text { field }(n=3)\end{array}$} & Low & 10.0 & 8.0 & 6.0 \\
\hline & High & 20.0 & 17.0 & 10.0 \\
\hline & Average & 15.0 & 12.5 & 8.0 \\
\hline
\end{tabular}

* No difference between values in this column and middle column
TABLE 3B. Acres per hour by operation at varying yields, San Joaquin Valley

\begin{tabular}{|c|c|c|c|c|}
\hline \multirow[t]{2}{*}{ Operation } & & 0.75 ton/acre & 1.25 tons/acre & 2 tons/acre \\
\hline & & \multicolumn{3}{|c|}{........ acres per hour......... } \\
\hline \multirow[t]{3}{*}{ Swath $(n=10)$} & Low & * & 5.0 & * \\
\hline & High & * & 16.0 & * \\
\hline & Average & 9.1 & 8.8 & 7.5 \\
\hline \multirow[t]{3}{*}{ Rake $(n=10)$} & Low & * & 12.0 & * \\
\hline & High & * & 35.0 & * \\
\hline & Average & 19.0 & 18.8 & 18.6 \\
\hline \multirow[t]{3}{*}{ Bale/small $(n=9)$} & Low & 6.0 & 5.0 & 4.0 \\
\hline & High & 20.0 & 15.0 & 10.0 \\
\hline & Average & 11.7 & 9.4 & 7.3 \\
\hline \multirow{3}{*}{$\begin{array}{l}\text { Haul small bales off } \\
\text { field }(n=5)\end{array}$} & Low & * & 10.0 & 7.5 \\
\hline & High & 31.0 & 25.0 & 18.0 \\
\hline & Average & 19.5 & 14.6 & 11.3 \\
\hline \multirow[t]{3}{*}{ Bale/large $(n=8)$} & Low & 10.0 & 9.0 & 8.0 \\
\hline & High & 50.0 & 40.0 & 30.0 \\
\hline & Average & 22.5 & 19.3 & 16.2 \\
\hline \multirow{3}{*}{$\begin{array}{l}\text { Haul large bales off } \\
\text { field }(n=4)\end{array}$} & Low & * & 13.0 & 7.2 \\
\hline & High & * & 50.0 & 30.0 \\
\hline & Average & 28.0 & 23.6 & 20.0 \\
\hline
\end{tabular}




\begin{tabular}{llll}
\multicolumn{2}{c}{ TABLE 4A. Custom rates by operation and job size with fixed yield } \\
of 2 tons/acre, intermountain region
\end{tabular}

\begin{tabular}{|c|c|c|c|c|}
\hline \multicolumn{5}{|c|}{$\begin{array}{l}\text { TABLE 4B. Custom rates by operation and job size with fixed yield } \\
\text { of } 1.25 \text { tons/acre, San Joaquin Valley }\end{array}$} \\
\hline \multirow[b]{2}{*}{ Operation(s), pricing } & & \multicolumn{3}{|c|}{ Job size } \\
\hline & & Smallest & Average & Largest \\
\hline \multirow[t]{3}{*}{ Swath $(n=5), \$$ per acre } & Low & * & 10.50 & * \\
\hline & High & * & 17.00 & * \\
\hline & Average & 12.96 & 12.70 & * \\
\hline \multirow[t]{3}{*}{ Rake $(n=5), \$$ per acre } & Low & 4.50 & 3.50 & * \\
\hline & High & * & 6.00 & * \\
\hline & Average & 5.20 & 5.00 & * \\
\hline \multirow[t]{3}{*}{ Swath and rake $(n=6), \$$ per acre } & Low & * & 14.00 & * \\
\hline & High & * & 22.00 & * \\
\hline & Average & 17.22 & 16.83 & * \\
\hline \multirow[t]{3}{*}{ Small bale: Bale $(n=5), \$ /$ bale } & Low & * & 0.75 & * \\
\hline & High & 1.10 & 1.00 & * \\
\hline & Average & 0.95 & 0.92 & * \\
\hline \multirow{3}{*}{ Swath, rake and bale $(n=2), \$$ ton } & Low & * & 27.00 & * \\
\hline & High & * & 29.00 & * \\
\hline & Average & * & 28.00 & * \\
\hline \multirow[t]{3}{*}{ Small bale: Haul off field $(n=2), \$ /$ bale } & Low & * & 0.36 & * \\
\hline & High & * & 0.40 & * \\
\hline & Average & * & 0.38 & * \\
\hline \multirow{3}{*}{$\begin{array}{l}\text { Small bale: Aggregated total hay charge } \\
\text { with hauling }(n=3), \$ \text { ton }\end{array}$} & Low & * & 30.00 & * \\
\hline & High & * & 39.14 & * \\
\hline & Average & 35.45 & 34.03 & * \\
\hline \multirow{3}{*}{$\begin{array}{l}\text { Small bale: Aggregated total hay charge } \\
\text { without hauling }(n=4), \$ \text { ton }\end{array}$} & Low & * & 21.91 & * \\
\hline & High & * & 29.00 & * \\
\hline & Average & * & 26.41 & * \\
\hline \multirow[t]{3}{*}{ Large bale: Bale $(n=5), \$ /$ bale } & Low & * & 7.50 & 6.50 \\
\hline & High & * & 11.00 & * \\
\hline & Average & 9.50 & 9.10 & * \\
\hline \multirow[t]{3}{*}{ Large bale: Haul off field $(n=2)$, $\$$ /bale } & Low & * & 3.00 & * \\
\hline & High & * & 3.90 & * \\
\hline & Average & * & 3.50 & * \\
\hline \multirow{3}{*}{$\begin{array}{l}\text { Large bale: Aggregated total hay charge } \\
\text { with hauling }(n=3), \$ \text { ton }\end{array}$} & Low & * & 30.00 & * \\
\hline & High & * & 40.90 & * \\
\hline & Average & * & 35.30 & * \\
\hline \multirow{3}{*}{$\begin{array}{l}\text { Large bale: Aggregated total hay charge } \\
\text { without hauling }(n=4) \text {, \$/ton }\end{array}$} & Low & * & 24.00 & * \\
\hline & High & * & 29.00 & * \\
\hline & Average & * & 26.70 & * \\
\hline
\end{tabular}

* No difference in value between rates in this column and middle column; signifies rate clustering. both regions. At all yield levels, those functions favored large bales (table 3). Statistical $t$-tests indicated a clear difference in the baling capacities per hour of large versus small balers in our sample. This is a major result because it indicates why custom harvesters may prefer to make large bales: they require less time, hence labor costs are reduced per job and, possibly, more jobs can be completed per year.

Job size. The average size of harvest jobs, expressed as total acres, differed significantly between the two regions (table 2) and affected harvester costs and rates. Harvesters tended to charge more per unit of output for small harvest jobs than for average or large jobs (table 4). This is true when harvesting prices are expressed as a single charge per ton, as is common in the intermountain region, and when they are priced separately for each operation, as in the San Joaquin Valley. (For example, swathing and raking in the San Joaquin Valley are typically charged per acre and baling and hauling are priced per bale.) Harvesters appear to be pricing each job separately, and some harvesters may be pricing jobs based on fixed costs per job rather than for total acres served annually, as would be expected. Harvest costs appear to be affected by job-specific factors such as the shape and condition of the field and distances the equipment must be moved to reach a job site.

In addition, custom rates on a perton basis tended to go down as yields increased for an average job size, but surprisingly, not in consistent amounts across the range of yields. The rates charged to growers decreased between low and average yields, but did not decrease as much between average and high yields (tables 5A and 5B). As hypothesized, harvesters charged less for large bales than they did for small bales.

\section{Rate-setting practices}

In California, the prices for harvesting services are presently expressed in two different ways: rates per acre and rates per ton. Both alfalfa growers (for whom this is a business cost) and custom hay harvesters (for whom this represents the price of their services) have expressed some dissatisfaction with each of these methods. Neither 
seems to fit all situations. For example, custom harvesters want to charge on a per-ton basis when yields are high, while growers want to pay on a per-acre basis. The reverse is true when yields are low. Either the grower or the custom harvester may be dissatisfied at any particular time.

However, our survey results indicated that the rates custom harvesters charge alfalfa growers are more often correlated with the costs of harvesting tasks as expressed on a per-ton basis, but not perfectly so. For example, higher yielding fields slowed down the harvesting process (table $3 \mathrm{~A}$ ), causing higher variable costs to be incurred per acre by the harvester, yet the rates being charged by harvesters were lower per acre for higher yielding fields (table 5A). This implies that some bargaining takes place between harvesters and growers, with rates more often quoted on a perton basis, and that some factors other than direct costs are considered during the rate-setting process.

The survey results also indicated that the two most common methods of setting rates are to focus either on variable costs or on fixed costs, with minimum rates set according to those cost levels. Focusing on variable costs led harvesters to set minimum rates per acre, while focusing on fixed costs resulted in minimum rates per job. Some harvesters used both methods; minimum rates help a harvester cover the costs of moving equipment and workers to each job site.

Many harvesters had a minimum charge per acre. In the intermountain region $60 \%$ had a minimum, which averaged $\$ 42.80$ per acre, and only $40 \%$ of San Joaquin Valley harvesters had a minimum, averaging $\$ 21.70$ per acre. The differences in minimums are due partly to the differences in average yields per cutting. Clearly, the two regions are separate markets.

Fewer harvesters used a minimum charge per job. In the intermountain region $40 \%$ charged a minimum, which averaged $\$ 500$ per job. Just $10 \%$ of harvesters in the San Joaquin Valley charged a minimum, averaging \$200 per job. Again the rate differences between regions reflect market conditions. Harvesters in the San Joaquin Valley have more jobs per year, on average, and
The ongoing transition from traditional bales of 125 pounds or less to large bales of 1,300 pounds or more is changing both the equipment and the hay market itself.

\begin{tabular}{llcc}
\multicolumn{2}{c}{ TABLE 5A. Custom rates for total hay harvest of average size jobs at varying yields, } \\
intermountain region
\end{tabular}

TABLE 5B. Custom rates by operation for average job size at varying yields, San Joaquin Valley

\begin{tabular}{|c|c|c|c|c|}
\hline \multirow[b]{2}{*}{ Operation(s), pricing } & & \multicolumn{3}{|c|}{ Average yield } \\
\hline & & 0.75 ton & 1.25 tons & 2 tons \\
\hline \multirow[t]{3}{*}{ Swath $(n=5), \$$ per acre } & Low & * & 10.50 & * \\
\hline & High & * & 17.00 & * \\
\hline & Average & 12.96 & 12.70 & * \\
\hline \multirow[t]{3}{*}{ Rake $(n=5), \$$ per acre } & Low & 4.50 & 3.50 & * \\
\hline & High & * & 6.00 & * \\
\hline & Average & 5.20 & 5.00 & * \\
\hline \multirow[t]{3}{*}{ Swath and rake $(n=6), \$$ per acre } & Low & * & 14.00 & * \\
\hline & High & * & 22.00 & * \\
\hline & Average & 17.90 & 17.40 & * \\
\hline \multirow[t]{3}{*}{ Small bale: Bale $(n=6), \$ /$ bale } & Low & * & 0.75 & * \\
\hline & High & 1.10 & 1.00 & * \\
\hline & Average & 0.95 & 0.92 & * \\
\hline \multirow[t]{3}{*}{ Swath, rake and bale $(n=2), \$$ ton } & Low & * & 27.00 & * \\
\hline & High & * & 29.00 & * \\
\hline & Average & * & 28.00 & * \\
\hline \multirow[t]{3}{*}{ Small bale: Haul off field $(n=2), \$ /$ bale } & Low & * & 0.36 & * \\
\hline & High & * & 0.40 & * \\
\hline & Average & * & 0.38 & * \\
\hline \multirow{3}{*}{$\begin{array}{l}\text { Small bale: Aggregated total hay charge } \\
\text { with hauling }(n=3), \$ / \text { ton }\end{array}$} & Low & * & 30.00 & 28.46 \\
\hline & High & 50.90 & 39.14 & 32.54 \\
\hline & Average & 42.43 & 34.03 & 30.33 \\
\hline \multirow{3}{*}{$\begin{array}{l}\text { Small bale: Aggregated total hay charge } \\
\text { without hauling }(n=4), \$ / \text { ton }\end{array}$} & Low & 27.00 & 21.90 & 17.71 \\
\hline & High & 37.30 & 29.00 & * \\
\hline & Average & 31.11 & 27.90 & 26.11 \\
\hline \multirow[t]{3}{*}{ Large bale: Bale $(n=2), \$ /$ bale } & Low & $*$ & 7.50 & 6.50 \\
\hline & High & * & 11.00 & * \\
\hline & Average & 9.50 & 9.10 & * \\
\hline \multirow{3}{*}{$\begin{array}{l}\text { Large bale: Haul bales off field }(n=2) \text {, } \\
\$ / \text { bale }\end{array}$} & Low & * & 3.00 & * \\
\hline & High & * & 3.90 & * \\
\hline & Average & * & 3.50 & * \\
\hline \multirow{3}{*}{$\begin{array}{l}\text { Large bale: Aggregated total hay } \\
\text { charge with hauling }(n=3), \$ / \text { ton }\end{array}$} & Low & * & 30.00 & * \\
\hline & High & 45.70 & 36.10 & 35.00 \\
\hline & Average & 36.90 & 33.70 & 31.90 \\
\hline \multirow{3}{*}{$\begin{array}{l}\text { Large bale: Aggregated total hay } \\
\text { charge without hauling }(n=4), \$ \text { ton }\end{array}$} & Low & 27.00 & 24.00 & 18.60 \\
\hline & High & 33.60 & 29.00 & * \\
\hline & Average & 29.90 & 26.70 & 24.90 \\
\hline
\end{tabular}




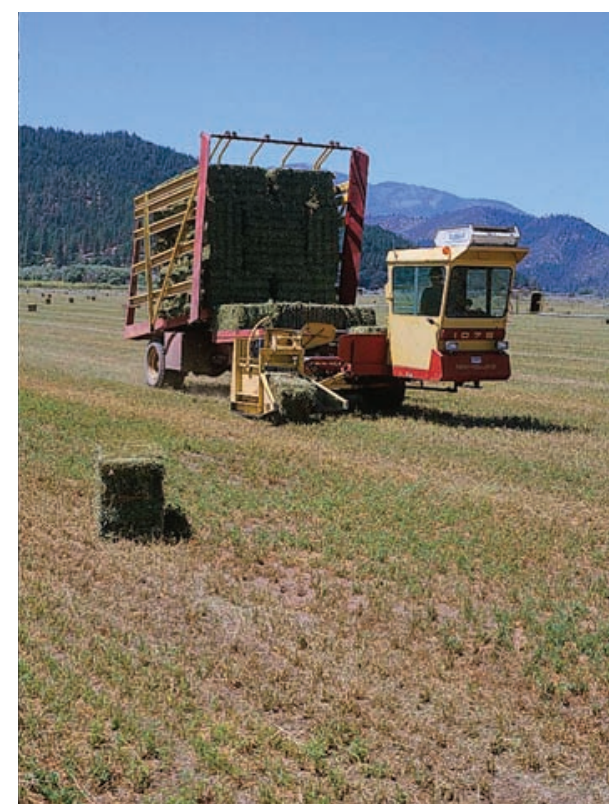

Small bales averaging about 125 pounds are collected in a bale wagon in Scott Valley (Siskiyou County).

those jobs tend to be larger in size so that fixed costs (and possibly variable costs) can be spread wider, resulting in lower minimum rates than those charged by harvesters in the intermountain region.

Harvesters were also asked to explain how they believe custom rates should be set. About two-thirds or $67 \%$ thought that custom charges should be calculated by a combination of factors, while $13 \%$ thought they should be based on yield only and $7 \%$ based on acreage only. Reasons given for responses favoring only one factor were "can't think of a better way to do it" and "otherwise it is too complicated." Many reasons were given for basing rates on a combination of factors. Some of the most common were:

- There is no one-size-fits-all method.

- A large, high-yielding field can have a lot of problems that drive costs up for the harvester.

- What is important is tonnage per hour, and many factors go into this.

- It must make economic sense to run a machine, and this is not determined by any one factor.

We found that rate setting is a competitive process, but not perfectly so. In a competitive market, prices for fairly standardized services, like custom hay harvesting within a geographic area, are expected to be clustered in a narrow range as different firms bid against one another for jobs. This does not mean that different harvesters will offer the

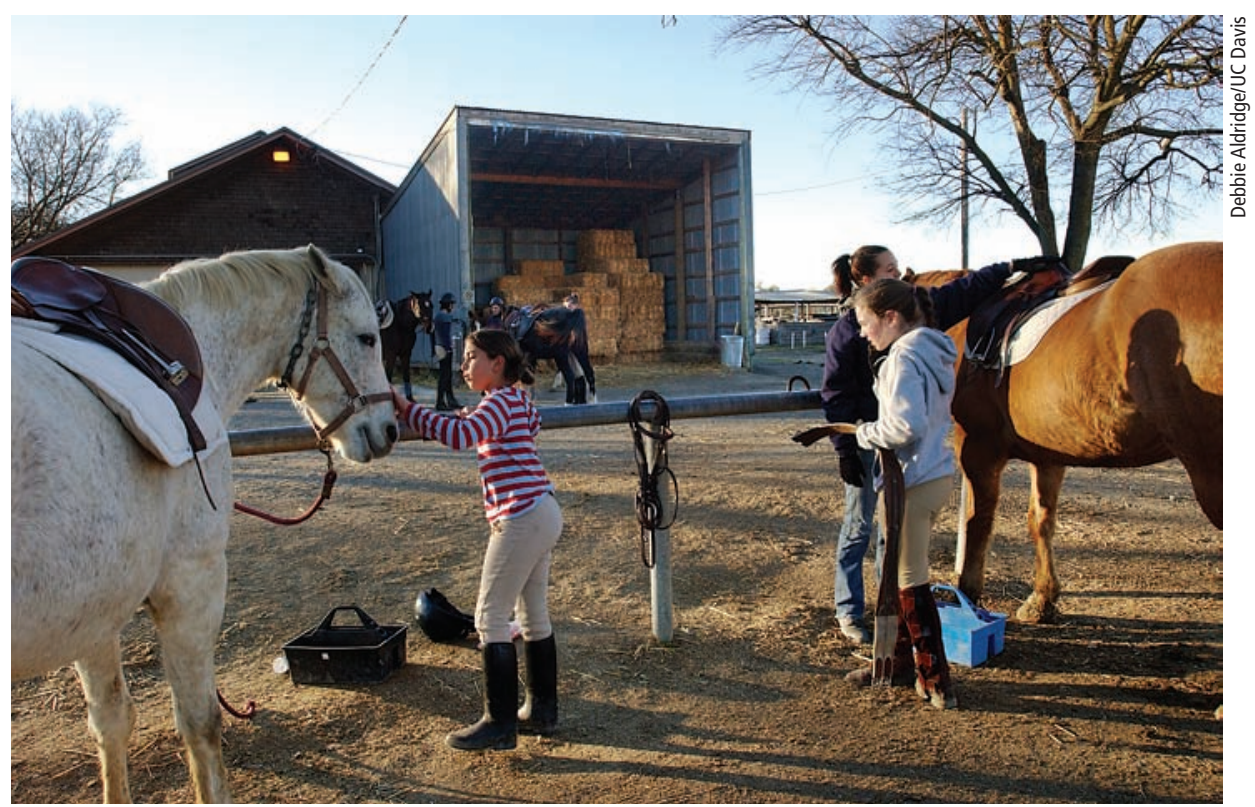

If the trend toward large bales continues, equestrians may be forced to pay higher prices as the supply of small bales declines. Above, girls prepare for a lesson at the UC Davis Equestrian Center.

same price to a particular grower. Fixed costs vary among custom harvesters resulting in differences in rates. Yet, the rates showed obvious signs of clustering within each region (tables 4 and 5). For example, in the tables, an asterisk denotes where there is no difference in the value for that column compared to the value in the middle column in that row; a high number of asterisks signals rate clustering.

The competitive aspect of rate setting by custom harvesters means that the cost differences between large and small bales will influence rates to some degree. Specifically, the time savings that come from making large bales compared to small bales enables harvesters to offer growers lower rates for large bales, on average. This, in turn, creates an incentive for growers to request that their alfalfa be made into large hay bales.

\section{Market implications}

The cost differences between small and large bales create economic incentives for custom harvesters to purchase new balers that produce large bales, potentially reducing supplies of small bales and reducing access to hay supplies for many small-scale retail hay consumers, such as horse owners. This raises the question of whether small-bale consumers will have to pay higher prices to maintain access to hay supplies. The market for large bales which includes dairy operations and cattle producers - may see hay prices decline relative to prices for the same volume in small bales, due to both the reduced cost of production and the increased supply of large bales. However, the market for small bales may shrink in size unless consumers pay higher prices to get the product in smallbale form. In essence, hay production changes are causing hay market segments to be redefined.

S. Blank and K. Klonsky are Extension Economists, and K. Fuller was Research Assistant, Department of Agricultural and Resource Economics, UC Davis; S. Orloff is Farm Advisor, UC Cooperative Extension, Siskiyou County; and D.H. Putnam is Extension Agronomist, Department of Plant Sciences, UC Davis.

\section{References}

Blank S, Klonsky K, Norris K, Orloff S. 1992. Acquiring Alfalfa Hay Harvest Equipment: A Financial Analysis of Alternatives. Giannini Foundation Information Series, 92-1, December.

Blank S, Orloff S, Putnam D. 2001. Sequential stochastic production decisions for a perennial crop: The yield/quality tradeoff for alfalfa hay. J Ag Res Econ 26:195-211.

Hopper J, Peterson H, Burton Jr R. 2004. Alfalfa hay quality and alternative pricing systems. J Ag Appl

Konyar K, Knapp K. 1990. Dynamic regional analysis of the California alfalfa market with government policy impacts. West J Ag Econ 15:22-32.

Ward CE. 1987. Buyer preferences for alfalfa hay attributes. N Centr J Ag Econ 9:289-96. Econ 36(3):675-90. 